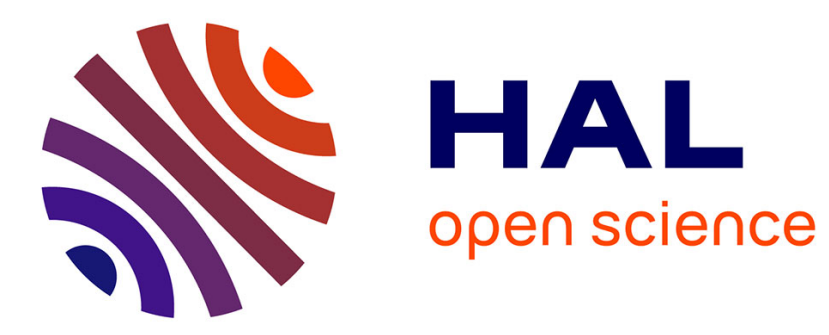

\title{
In-situ protein determination to monitor contamination in a centrifugal partition chromatograph
}

Fériel Bouiche, Karine Faure

\section{To cite this version:}

Fériel Bouiche, Karine Faure. In-situ protein determination to monitor contamination in a centrifugal partition chromatograph. Analytical Biochemistry , 2017, 525, pp.23-28. 10.1016/j.ab.2017.02.015 . hal-01518929

\author{
HAL Id: hal-01518929 \\ https://hal.science/hal-01518929
}

Submitted on 23 Jul 2020

HAL is a multi-disciplinary open access archive for the deposit and dissemination of scientific research documents, whether they are published or not. The documents may come from teaching and research institutions in France or abroad, or from public or private research centers.
L'archive ouverte pluridisciplinaire HAL, est destinée au dépôt et à la diffusion de documents scientifiques de niveau recherche, publiés ou non, émanant des établissements d'enseignement et de recherche français ou étrangers, des laboratoires publics ou privés. 


\title{
IN-SITU PROTEIN DETERMINATION TO MONITOR CONTAMINATION IN A CENTRIFUGAL PARTITION CHROMATOGRAPH
}

Feriel Bouiche ${ }^{1,2}$, Karine Faure ${ }^{1}$

${ }^{1}$ Univ Lyon, CNRS, Université Claude Bernard Lyon 1, Ens Lyon, Institut des Sciences Analytiques, CNRS, 5 rue de la Doua, F-69100 Villeurbanne, France

${ }^{2}$ Kromaton Sarl, groupe Rousselet-Robatel, 45 Avenue Rhin et Danube, 07100 Annonay, France

\begin{abstract}
Centrifugal partition chromatography (CPC) works with biphasic liquid systems including aqueous two-phase systems. Metallic rotors are able to retain an aqueous stationary phase able to purify proteins. But the adhesion of proteins to solid surface may pose a cross-contamination risk during downstream processes. So it is of utmost importance to ensure the cleanliness of the equipment and detect possible protein contamination in a timely manner. Thereby, a direct method that allows the determination of the effective presence of proteins and the extent of contamination in the metallic CPC rotors was developed. This in-situ method is derived from the Amino Density Estimation by Colorimetric Assay (ADECA) which is based on the affinity of a dye, Coomassie Brillant Blue (CBB), with protonated $\mathrm{N}^{+}$groups of the proteins. In this paper, the ADECA method was developed dynamically, on a $25 \mathrm{~mL}$ stainless-steel rotor with various extents of protein contaminations using bovine serum albumin (BSA) as a fouling model. The eluted CBB dye was quantified and found to respond linearly to BSA contamination up to $70 \mathrm{mg}$ injected. Limits of detection and quantification were recorded as 0.9 $\mathrm{mg}$ and $3.1 \mathrm{mg}$, respectively. While the non-specific interactions between the dye and the rotor cannot currently be neglected, this method allows for in situ determination of proteins contamination and should contribute to the development of CPC as a separation tool in protein purification processes.
\end{abstract}

\section{Keywords}

Centrifugal partition chromatography, countercurrent chromatography, proteins contamination, Coomassie Brillant Blue, Bovine serum albumin.

\section{Abbreviations}

CPC : Centrifugal partition Chromatography

BSA : Bovin Serum Albumin

ADECA: Amino Density Estimation by Colorimetric assay

PBS: Phosphate Buffer Salin

CBB: Coomassie Brillant Blue

FDA: Food Drug Administration

pI: Isoelectric point 
Centrifugal liquid-liquid chromatography, including counter-current chromatography (CCC) and centrifugal partition chromatography (CPC), is a chromatographic separation technique based on the partition of solutes between two immiscible liquid phases with no solid support (1-3). One of the two immiscible phases is retained in the column by centrifugal force fields; it is called the stationary phase. The other phase is the mobile phase; it percolates through the stationary one. CCC and CPC have numerous advantages such as a high loading capacity and no loss of solute since it is always possible to recover any material trapped in a liquid phase. These advantages were used over the past years to purify biomolecules, especially proteins, by CCC and CPC modes $(4,5)$. Aqueous Two Phase Systems (ATPS) were found very efficient for protein purification $(6,7)$. As their name says, ATPSs are composed by two immiscible aqueous phases. This is obtained either dissolving two polymers in water or dissolving a polymer and a salt or an ionic liquid and a salt. ATPSs combine a high biocompatibility and selectivity for biomolecules (8). These solvent systems were proved effective in biopurification due to their high water content and low interfacial tension, which make them gentle towards proteins $(9,10)$. However, $\mathrm{CCC}$ was found unable to retain efficiently an aqueous liquid stationary phase likely due to the low ATPS interfacial tension (3). CPC, with its constant centrifugal field and its rotor of interconnected chambers was able to retain ATPSs allowing for protein purification (1-3).

One of the issues when working with proteins is the risk of contamination of the CPC equipment. Indeed proteins can easily adsorb on the rotor material. Adhesion of proteins to solid surface can occur under various conditions and cause problems for biotechnology manufacturers. For example, in case of food manufacturing, proteins can form a fouling which is an unwanted deposit on the equipment surface (11). Thereby, an insufficient cleaning may result in the development of bacteria and biofilm formation (12). Moreover, the adherent proteins may pose a cross contamination risk (13). For these safety reasons, the cross-contamination risks are strictly controlled through governmental organizations, such as the U.S Food and Drugs Administration (FDA). These Agency documents clearly establish the required expectation for cleaning procedure validation (14). CPC is no exception. So, one of the most important issues for its development in the protein industry is to ensure the cleanliness of the equipment after a purification in order to avoid cross-contamination and hence to be able to detect protein contamination.

A cleaning method was specifically developed by Chollet (15) for CPC rotors. This method consists in alternate rinsing steps of water, $0.5 \mathrm{M}$ sodium hydroxide solution and sulfuric acid solution at $2.10^{-5} \mathrm{M}$, repeated twice. While it follows the FDA standards and the Good Manufacturing Practice (GMP), this method is only available in French. The validity of the cleaning procedure is controlled either by visual criterion opening the rotor and swiping the disks surface, or by the protein determination in the various rinse solutions via the Bradford method (16). Unfortunately, the ultimate rinsing solutions are highly diluted, and their analysis requires a highly sensitive detection system. Although the validation of the cleaning protocol by swiping is soundproof, it is only accessible to instrument suppliers, as it requires the mechanical opening of the rotor. The industrial users do not have the facilities to tighten disks and to equilibrate weights after closure of this rotating device.

In the present work we propose an in-situ strategy to determine the state of protein contamination inside the rotor without opening the machine. This in-situ method derived from the Amino Density Estimation by Colorimetric Assay (ADECA) method (17). This method was established to rapidly quantify grafted proteins on a solid support such as 96-well plates. It is based on the affinity of a dye, the Coomassie Brillant Blue (CBB), with protonated amino groups. The ADECA method consists in three steps: first a fixation step (or staining) ensures that the dye is bound to the surface material by an $\mathrm{N}^{+}$-dye complex formation. Next a washing step removes any unbound dye. Last, the dye bounded to proteins is eluted by a $\mathrm{pH}$ switch which breaks the $\mathrm{N}^{+}$-dye complex and the quantification of grafted protonated groups is directly related to the amount of released CBB dye. Thereby, this method should accurately indicate if any traces of proteins remain in a rotor after a full cleaning. The CBB dye would stick to such traces and any blue color seen during the acid wash would point remaining proteins. To set up this method in CPC instruments, we applied the ADECA protocol to a commercial $25 \mathrm{~mL}$ stainless steel rotor and the optimal conditions were determined. A graduated range of protein contamination was simulated using bovine serum albumin. 
92

93

94

95

96

97

\section{Materials}

The dye Coomassie Brillant Blue CBB-G250 (CBB, $>99 \%, \mathrm{C}_{45} \mathrm{H}_{44} \mathrm{~N}_{3} \mathrm{NaO}_{7} \mathrm{~S}_{2}, \mathrm{MW}=854 \mathrm{~g} / \mathrm{mol}, \mathrm{a}$ triphenylmethane dye with two benzene-sulfonic acid and three amine groups), potassium carbonate ( $>99.5 \%$; $\mathrm{MW}=138.2 \mathrm{~g} / \mathrm{mol})$, potassium bicarbonate $(>99.5 \%$; MW=100.12 $\mathrm{g} / \mathrm{mol})$ and phosphate buffer saline (PBS) as well as the protein bovine serum albumin (BSA 96\%, MW=66463, pI=4.7) were from Sigma Aldrich (SaintQuentin Fallavier, France). Ethanol absolute was from ThermoFisher (Villebon-sur-Yvette, France).

The $\mathrm{pH}$ measurements are performed in the overall hydroorganic solution. The effective hydrogen activity in aqueous/organic solutions can be only estimated using water calibrated pHmeter and will be stated as "apparent $\mathrm{pH}$ ".

\section{Instrumentation}

The CPC instrument is a hydrostatic apparatus model, FCPC-A from Kromaton Rousselet-Robatel (Annonay, France) with interchangeable rotors. A stainless steel 316 rotor with a volume of $25 \mathrm{~mL}$ was mainly used in this study. For comparative assays, two prototype rotors were assessed: a stainless steel 316 rotor with a volume of $80 \mathrm{~mL}$ and a titanium rotor with a volume of $46 \mathrm{~mL}$. The internal surface was calculated thanks to the cell and channel dimensions provided by the manufacturer and was evaluated at $0.38 \mathrm{~m}^{2}$ for the $25 \mathrm{~mL}$ rotor, $0.61 \mathrm{~m}^{2}$ for the $80 \mathrm{~mL}$ rotor and $0.31 \mathrm{~m}^{2}$ for the $46 \mathrm{~mL}$ titanium rotor.

A Spot Prep II integrated system from Armen Instruments (Saint-Avé, France, Gilson USA) was used. This equipment is the assembly of a quaternary pump, an automatic loop injection valve fitted with a $1 \mathrm{~mL}$ sample loop, a UV/Vis spectrophotometer dual wavelength set up at $259 \mathrm{~nm}$ and $280 \mathrm{~nm}$ and a fraction collector.

\section{Rotor cleaning procedure}

After protein impregnation and/or ADECA implementation, the used rotors were fully cleaned according to Common Industrial Protocol, i.e. alkaline solution $\mathrm{pH}$ 14, for the equivalent of 3 column volumes.

\section{Preparation of solutions}

Solutions for the staining step were prepared by dissolving $500 \mathrm{mg}$ of CBB in $100 \mathrm{~mL}$ of ethanol and $50 \mathrm{~mL}$ of glacial acetic acid $\left(\mathrm{CH}_{3} \mathrm{COOH}\right)$ and stirred. After complete dissolution, deionized water was added up to a final volume of 1 Liter. The final composition of the staining solution was $0.05 \%(\mathrm{w} / \mathrm{v}) \mathrm{CBB}, 10 \%$ ethanol, $5 \%$ $\mathrm{CH}_{3} \mathrm{COOH}$ and $85 \% \mathrm{H}_{2} \mathrm{O}(\mathrm{v} / \mathrm{v})$. The apparent $\mathrm{pH}$ is 2.4 .

The composition of the washing solution was the same as that of the staining solution, i.e. $10 \%$ ethanol, $5 \%$ $\mathrm{CH}_{3} \mathrm{COOH}$ and $85 \% \mathrm{H}_{2} \mathrm{O}(\mathrm{v} / \mathrm{v})$ but with no CBB. For $\mathrm{pH}$ studies in the range 2.4 to 12 , acetic acid or potassium carbonate was added until the desired target $\mathrm{pH}$ was reached.

The composition of the elution solution was 50\% (v/v) EtOH and 50\% carbonate buffer $\mathrm{pH} 12$.

\section{Extent of proteins contamination in various rotors}

Five BSA proteins standard solutions were prepared in the range of $0 \mathrm{mg} / \mathrm{mL}$ to $200 \mathrm{mg} / \mathrm{mL}$ in phosphate buffer saline (PBS) $\mathrm{pH}=7.4$ or in carbonate buffer $\mathrm{pH}=9$ and $\mathrm{pH}=12$. The simulated contaminations were performed on a clean rotor by injecting $1 \mathrm{~mL}$ of protein solution in the rotor using the chromatographic system then rinsing by the buffer solution. It was previously checked that no significant adsorption happens in PEEK tubings and in the injection device. Blanks were performed by injecting phosphate buffer without protein. 
The ADECA method developed to quantify the amount of grafted proteins on a surface contains three different steps. To transfer this static method performed in 96-well plates to a dynamic method in CPC rotor, the three ADECA steps were adapted as follows: A-The staining step was carried out pumping the staining solution at 10 $\mathrm{mL} / \mathrm{min}$ during $15 \mathrm{~min}$; i.e a volume of $150 \mathrm{~mL}$ staining solution; B-The washing step was achieved with a flow rate of $10 \mathrm{~mL} / \mathrm{min}$ during $18 \mathrm{~min}$ unless stated otherwise. C-The elution step was realized by pumping the elution solution at $10 \mathrm{~mL} / \mathrm{min}$ during $15 \mathrm{~min}$ through the rotor.

During all these different steps the rotor was not set in rotation and detection was performed at $259 \mathrm{~nm}$ which corresponds to the maximum of the dye absorbance in the UV region.

\section{Detector calibration}

To relate the CBB peak area to the amount of proteins to which CBB molecules were bound, a calibration of the UV detector is necessary. First of all the detector was calibrated with different proteins solutions with an increasing concentration of CBB in the range $0.6-200 \mathrm{mg} / \mathrm{mL}$ injecting $1 \mathrm{~mL}$ each time. Then it was calibrated by the CBB solution in the range $0.1-13.5 \mathrm{mg} / \mathrm{mL}$ in the acidic blue form ( $\mathrm{pH} 2.4,10 \%$ ethanol $/ 5 \%$ acetic acid) and in the range $0.1-25 \mathrm{mg} / \mathrm{mL}$ in its basic redish form $(\mathrm{pH} 12$, carbonate/ethanol $(50 / 50 \mathrm{v} / \mathrm{v})$ in order to determine the linearity range of the detector for these solutions. Each injection was repeated three times.

\section{Results and Discussions}

\section{Extent of proteins contamination}

Protein adsorption occurs when a protein solution comes in contact with a solid surface (18). Centrifugal partition chromatography is a preparative downstream process, handling very concentrated protein solutions $(\mathrm{g} / \mathrm{L}$ to hundredth of $\mathrm{g} / \mathrm{L}$ range). During method developments, rotor contaminations by proteins were noted by users. To check these observations, a $25 \mathrm{~mL}$ commercially available rotor made of stainless steel was intentionally stained by proteins at different $\mathrm{pHs}$. The surface contamination can be linked to solid surface properties, solution conditions and proteins properties (19). Stainless steel surfaces are known to form an oxide layer covered by hydroxyl groups whose charge may strongly affects adsorption properties. According to the literature (20), the stainless steel surface has positive charge above $\mathrm{pH} 8.5$ and is neutral above this value. In order to study the $\mathrm{pH}$ effect of the surface nature on the extent of protein contamination, different amounts of BSA were introduced at different $\mathrm{pHs}$ from 7.4 (physiological $\mathrm{pH}$ ) to 12 . Figure 1 shows the quantity of residual proteins (ADECA method) inside the $25 \mathrm{~mL}$ stainless steel rotor in regards to the quantity of injected proteins at different $\mathrm{pH}$ values.

The residual protein quantity was determined by subtracting the amount of proteins eluting from the rotor after washing with one column volume. The contamination is linearly related to the amount of injected proteins (Fig. 1). Surprisingly, saturation of the surface is not attained with the BSA protein reaching density values as high as $100 \mathrm{mg} \mathrm{BSA} / \mathrm{m}^{2}$, while for the same 316 stainless steel it was said that saturation occured around $3 \mathrm{mg} \mathrm{BSA} / \mathrm{m}^{2}$ stainless steel (20). What is more surprising is that the adsorption lines have a slope around 0.19 that does not depend on $\mathrm{pH}$ (Fig. 1). The BSA isoelectric point being 4.7, the protein is overall negatively charged for all experiments. At $\mathrm{pH} 7.4$, the stainless steel surface is positively charged and BSA would be supposed to adsorb through charge-charge interactions through carboxyl groups. However, at $\mathrm{pH} 9$ and 12, the stainless steel surface has a zero charge density, thus proteins contamination should be lesser. Since no difference was observed, it confirms that the binding between stainless steel and proteins is not only controlled by the stainless steel surface charge but also through dipole-dipole interactions, hydrogen bonding and coordination bonding.

All these results show that contamination of CPC rotors with BSA is indeed happening. Therefore a method to detect proteins contamination should be welcome by users. For further study, the BSA staining was done at $\mathrm{pH}$ 7.4 which corresponds to the physiological $\mathrm{pH}$.

\section{ADECA based on the $N+$-dye interaction.}

The three steps of the ADECA method have to be optimized to ensure a reproducible protocol. The staining solution should maximize the CBB-protein interaction. The dye CBB exists under three different forms: cationic 
form at $\mathrm{pH}$ below 3, neutral form at $\mathrm{pH}$ between 3 and 12 and anionic form at $\mathrm{pH}$ above $12(21,22)$. In order to allow the N+-CBB interaction, the protein net charge should be positive and the CBB sulfonic acid groups should be negatively charged. The first condition is better fulfilled for $\mathrm{pH}$ below 4.7 (BSA isoelectric point). In order to quantitatively relate the amount of $\mathrm{CBB}$ to the amount of proteins, the $\mathrm{pH}$ condition was selected so that only one site $\mathrm{NH}+$ is bounded to the $\mathrm{CBB}$ molecule. This is possible at $\mathrm{pH}$ below 3 , so staining was achieved at pH 2.4 (17). Besides, for staining to be complete, the dye was injected in excess and solubilized in $10 \%$ ethanol.

The washing step must remove the dye located in the void volume and also the background staining due to nonspecific binding on native rotor material. The free dye must be highly soluble in the washing solution that should not disrupt the $\mathrm{N}^{+}$-CBB interactions on rotor material. In order to maintain $\mathrm{N}^{+}$-CBB interactions, the $\mathrm{pH}$ of the washing solution should be the same as that of the staining step, i.e. pH 2.4.

The elution step must dissociate quantitatively the $\mathrm{N}^{+}$-CBB interactions. To allow this dissociation, the charge of the $\mathrm{CBB}$ or of the proteins has to be modified. At $\mathrm{pH} 12.4$, both BSA and CBB become negatively charged, which generates ionic repulsion. However the pink basic CBB form is less soluble than the blue form (23). Thereby to avoid any CBB precipitation, the ethanol percentage was increased. According to Coussot (17) the maximum usable percentage of ethanol is $50 \%$ because the dye can also precipitate above this value.

\section{Application of a dynamic ADECA method in a stainless steel CPC rotor}

In order to simulate a protein contamination in a CPC rotor, an injection of $300 \mathrm{mg}$ of BSA at $\mathrm{pH} 7.4 \mathrm{was}$ performed in a commercial $25 \mathrm{~mL}$ stainless steel rotor and a subsequent ADECA protocol was performed to quantify the BSA staining. Figure 2 represents the UV detection signal at $259 \mathrm{~nm}$ that was recorded during the experiment. After the protein injection, a one-column volume of phosphate buffer saline is introduced at 10 $\mathrm{mL} / \mathrm{min}$, removing the non-adsorbed proteins. This elution out of the rotor produces a UV signal as a Gaussian peak, the shape being due to the Poiseuil dispersion through the column. As the detector was calibrated with known amounts of proteins in the same operating conditions, the eluting BSA can be quantitated and it can be deduced by subtraction that, after this phosphate buffer rinse step, a $67 \mathrm{mg}$ amount of BSA or $22 \%$ of the $300 \mathrm{mg}$ injected remains adsorbed in the rotor. In order to in-situ quantitate the extent of contamination, the dynamic ADECA method is implemented. The staining step corresponds to the introduction of the CBB dye in the $25 \mathrm{ml}$ rotor at a concentration of $500 \mathrm{mg} / \mathrm{L}$. A fixed volume of $150 \mathrm{~mL}(15 \mathrm{~min}$ elution at $10 \mathrm{~mL} / \mathrm{min})$ of staining solution allowed the saturation of the interacting sites. The excess dye that does not interact with $\mathrm{N}+$ elutes out of the rotor, which is translated to an increase of the UV signal at $259 \mathrm{~nm}$ (part A in Figure 2). The staining step was optimized both in terms of thermodynamic aspects (concentration of the dye an its overall quantity) and on the kinetic aspects (contact time, flow rate of introduction). The flow rate had no effect on the quantity of bounded CBB.

The washing step must remove any CBB molecule that is not bound to BSA, without breaking the N+-dye interaction. As the rotor is filled with the staining solution containing CBB dye, introducing a solution without any absorbing molecule results in a decrease of UV signal (part B in Figure 2). The baseline return ensures that all unbound dye has been washed off. This extensive washing corresponds to 10 times the volume of the rotor.

Finally the elution step is performed by the introduction of a $\mathrm{pH} 12$ organic-carbonate solution which breaks the interaction between $\mathrm{CBB}$ and $\mathrm{N}+$. The $\mathrm{CBB}$ release is almost instantaneous as $\mathrm{pH}$ changes. This result in a CBB peak that moves at the elution solution velocity (part $\mathrm{C}$ in Figure 2). The peak area is related to the amount of released $\mathrm{CBB}$, hence to the amount of stainless steel bound BSA.

In order to check if the peak signal from step $\mathrm{C}$ is not due to some protein release after the basic $\mathrm{pH}$ switch, a blank experiment was performed injecting $100 \mathrm{mg}$ of proteins in the $25 \mathrm{~mL}$ stainless steel rotor followed by the ADECA protocol without any CBB dye. Since no UV absorption was observed in the elution step, it means that, to the extent of our detection level, no protein was released at that stage and hence the quantification of peak $\mathrm{C}$ relates only to $\mathrm{CBB}$ eluting molecules.

The ADECA method was also implemented in a clean rotor, that is to say, in a rotor onto which no protein was injected and after an extensive CIP cleaning procedure. The results are shown in Figure $2 \mathrm{~b}$. During the elution 
step $\mathrm{C}$, a peak is present, suggesting the presence of either CBB fouling in dead volumes or non-specific

interactions. In order to make sure that the retained CBB dyes are not just hold in any dead volume, the operating parameters of $\mathrm{CPC}$ rotor, i.e. flow rate and rotation speed, were studied to evaluate their impact on the nonspecific peak present in the step C. Indeed, in CPC rotor, the flow path is governed by hydrodynamic $(24,25)$. Thereby to create a powerful mobile phase spray that can extensively reach any part of the cell chamber, the rotation speed was set at $1800 \mathrm{rpm}$ and the flow rate up to $35 \mathrm{~mL} / \mathrm{min}$ during washing step. This did not affect the presence of the released CBB peak on blank experiments. Hence, the main cause of the background staining is due to the nonspecific CBB binding with native materials. Indeed, the staining step taking place at $\mathrm{pH} 2.4$, the stainless steel rotor has a positive charge at its outer layer surface while the CBB is negatively charged. Thereby, ionic interactions are generated between the rotor surface and the CBB during staining step (step A) and maintained during washing step (step B, same $\mathrm{pH}$ 2.4). The basic switch in elution step (step $\mathrm{C}$, $\mathrm{pH}$ 12) releases $\mathrm{CBB}$ by changing the material charge density, explaining the presence of an elution peak in a clean rotor.

The non-specific interaction between $\mathrm{CBB}$ and the stainless steel surface can be strongly reduced by controlling the charge density of the surface (Figure $3 \mathrm{~A}$ ). When the washing step was performed at $\mathrm{pH} 2.4,10 \%$ ethanol, the dye density due to non-specific interactions is estimated to be $9.0 \pm 0.4 \mathrm{mg} / \mathrm{m}^{2}$. Introducing washing solutions with higher $\mathrm{pHs}$ does not significantly improve the situation, till the $\mathrm{pH}$ reaches the value of 8.6. At this value, the stainless steel hydroxide layer becomes neutral and hence the interaction with the anionic $\mathrm{CBB}$ becomes weaker. The density of CBB was measured to be only $1.2 \pm 0.3 \mathrm{mg} / \mathrm{m}^{2}$. A further increase of $\mathrm{pH}$ up to 12 did not change the extent of non-specific interactions.

Because $\mathrm{CBB}$ is soluble in ethanol, we tried to further decrease the background staining by increasing the ethanol content in the washing solution. As shown in Figure 3B, this had a significant effect on reducing the nonspecific interactions: a washing solution with $30 \%$ ethanol and $\mathrm{pH} 8.6$ lead to the complete elimination of CBBmetal interaction.

Unfortunately, when implementing the ADECA protocol with a 30\% ethanol, $\mathrm{pH} 8.6$ washing step on a soiled rotor, the results showed that the specific CBB-protein binding was affected and hence the quantification was no longer reliable. This was also the case with a $10 \%$ ethanol, $\mathrm{pH} 8.6$ washing solution. Indeed, at $\mathrm{pH} 8.6$, the $\mathrm{BSA}$ is negatively charged and we suspect that ionic repulsion may occur between the negative dye and the protein.

Hence the accurate determination of protein fouling in a CPC rotor has to be performed with a $\mathrm{pH}$ switch from 2.4 to 12 and the background staining has to be taken into account.

Linearity, repeatability, quantification and limit of detection were studied under these conditions by creating a range of controlled stainings on the $25 \mathrm{mLstainless}$ steel rotor. Five proteins standard solutions were prepared in phosphate buffer solution in the range of 0 to $200 \mathrm{mg} / \mathrm{mL}$ and $1 \mathrm{~mL}$ injected led to a fouling extent in the range 0-70 $\mathrm{mg}$ (Figure 1), i.e a protein density on the stainless steel surface in the range $0-180 \mathrm{mg} / \mathrm{m}^{2}$. After each contamination, the ADECA protocol was conducted and the released CBB peak area was monitored (Figure 4). The rotor was then extensively washed before the next contamination. The linearity between the quantity of residual proteins in the column and the area of released CBB molecules was verified in the studied range with $\mathrm{r}^{2}>0.965$. The limits of detection and quantification were $0.9 \mathrm{mg}$ and $3.1 \mathrm{mg}$ respectively.

The same experiment was also set in a larger stainless steel rotor in order to study the influence of the available surface. A $80 \mathrm{~mL}$ prototype rotor from Kromaton, with cells four times larger than the commercialized $25 \mathrm{ml}$ rotor, but made of the same 316 stainless steel quality, was submitted to the very same controlled contamination. The calculated internal surface is $0.61 \mathrm{~m}^{2}$, to be compared to the $0.38 \mathrm{~m}^{2}$ of the commercialized $25 \mathrm{ml}$ rotor. Surprisingly, the limits of detection and quantification were respectively $0.9 \mathrm{mg}$ and $3.1 \mathrm{mg}$, the same as those of the $25 \mathrm{~mL}$ rotor. It is possible that the significant background staining plays an important role in these elevated values. 
Titanium is a favored material in biotechnology because it is known to be easily cleaned at high pHs compared to stainless steel (20). Using a very similar BSA staining process, the possibility to implement the ADECA procedure in a $46 \mathrm{~mL}$ titanium prototype rotor was investigated to assess the in-situ extent of contamination. However, the preliminary results showed that the titanium rotor was unexpectedly prone to protein adsorption. Titanium exhibits an isoelectric point of 4.5. The existence of this electric point suggests that the surface could be positively charged below $\mathrm{pH} 4.5$ and negatively charged above $\mathrm{pH} 4.5\left(-\mathrm{Ti}_{2} \mathrm{O}^{-}\right)$. Ionic interactions between titanium surface charges and protonated amino groups on aminoacid residues have already been observed (19). Working at $\mathrm{pH} 7.4$, the net BSA charge is weakly negative, so a large number of amino sites are available for interactions. Fouling is close to linear in regards to the injected amounts and the slope is similar to the one observed for contamination on stainless steel. Nonetheless, when calculating the fouling density, the values were out of range and saturation was reached at $160 \mathrm{mg} / \mathrm{m}^{2}$, which value does not match at all the reported value of 4 $\mathrm{mg} / \mathrm{m}^{2}(20)$. Hence we suspect that the manufacturing process for rotor engraving that differs from stainless steel, generates a rough surface and/or a high specific area, as confirmed by a noted ruggedness of the rotor titanium surface. The calculated $0.31 \mathrm{~m}^{2}$ surface of the $46 \mathrm{~mL}$ rotor is likely largely underestimated, while the effective internal surface of this titanium rotor is unfortunately not accessible.

The ADECA profiles for cleaned and contaminated titanium rotor were highly similar as the ones observed on stainless steel (Figure 2) and are not reproduced here. However, the non-specific interactions of CBB molecules on titanium surface were found much higher than on stainless steel with a much less accurate quantification.

\section{Conclusion}

298

\section{Aknowlegement}

KF and FB thanks the professor Alain Berthod for the support in this study. 


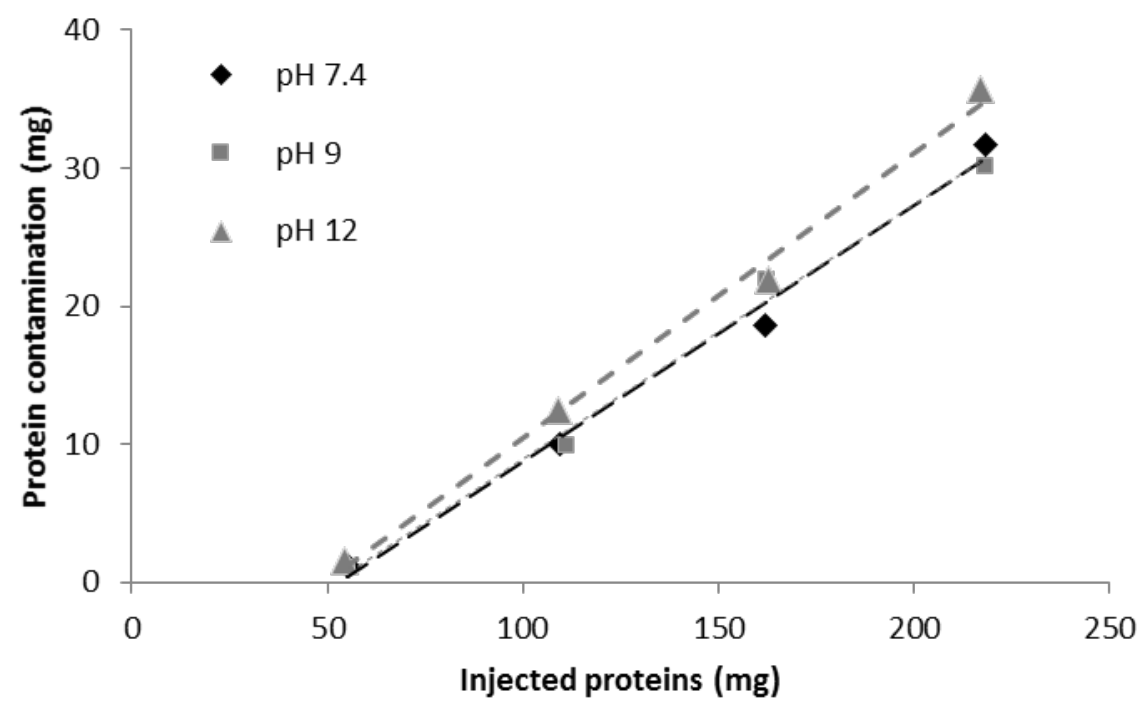

315

316 Figure 1. Relationship between the quantity of proteins injected in the stainless steel rotor and the remaining 317 proteins after a one-column buffer rinse at various $\mathrm{pHs}$.

318

319

320

321

322

323 

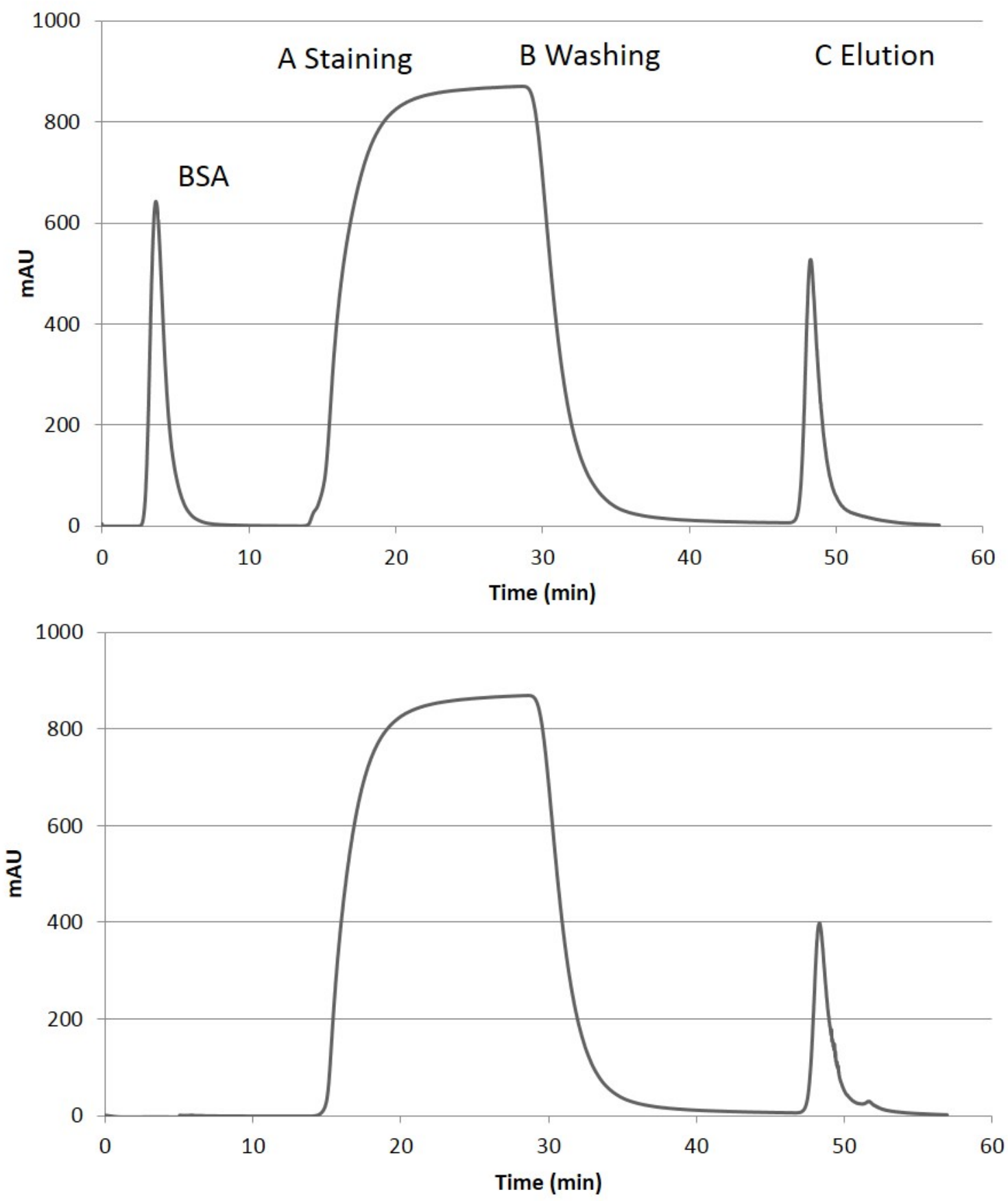

Figure 2. UV signal of the different ADECA steps on a $25 \mathrm{~mL}$ stainless steel rotor, (top) contaminated with BSA protein and (bottom) the $25 \mathrm{~mL}$ clean rotor with no protein contamination.

(top) at $0 \mathrm{~min}$, injection of $300 \mathrm{mg} \mathrm{BSA} \mathrm{pH} 7.4$ and one-column volume rinse by phosphate buffer saline solution $\mathrm{pH} 7.4$; (both) A- between 15 and 30 min, staining step with $0.05 \% \mathrm{CBB}, 10 \%$ ethanol, $\mathrm{pH}$ 2.4; Bbetween 30 and 45 min, washing step with $10 \%$ ethanol pH 2.4; C- at 45 min, CBB elution step $50 \%$ ethanol pH 12. Every dynamic step is performed at $10 \mathrm{~mL} / \mathrm{min} 0 \mathrm{rpm}$. Detection $259 \mathrm{~nm}$. 

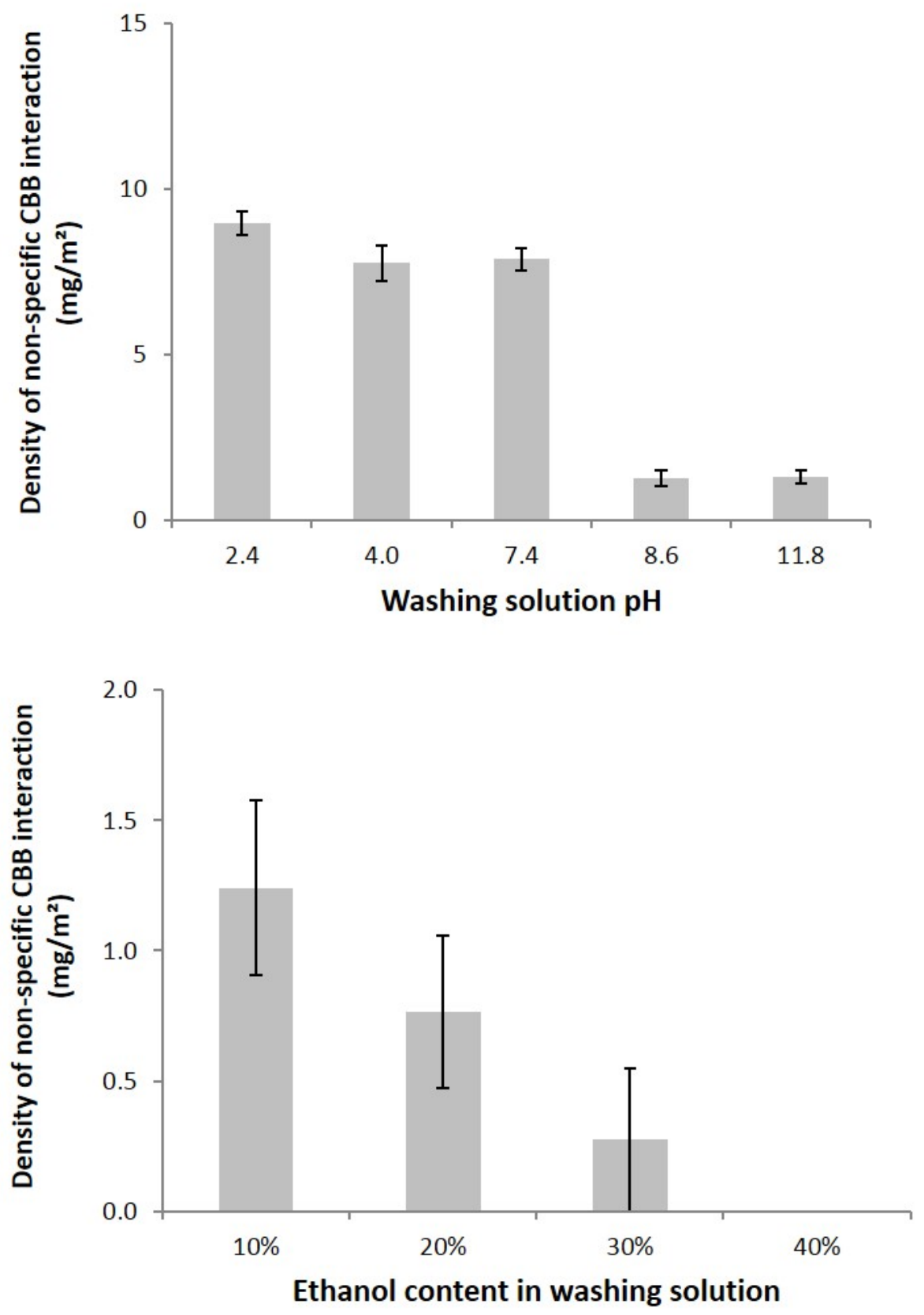

334

Figure 3 Evaluation of the non-specific CBB interaction expressed as the amount of CBB released after the 336 washing step done with (top) various $\mathrm{pHs}$ and $10 \% \mathrm{EtOH}$, (bottom) various ethanol contents at $\mathrm{pH}$ 8.6. 


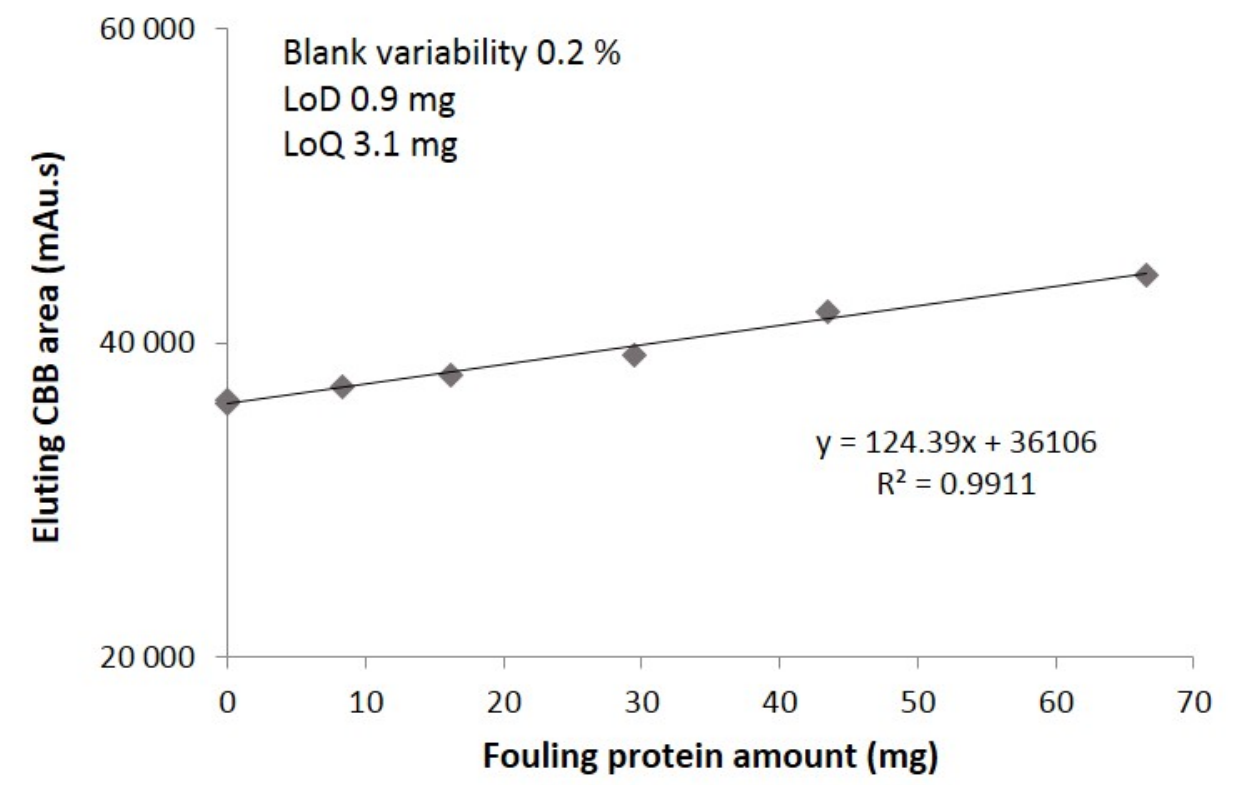

340

Figure 4 Calibration curve relating the amount of proteins in the stainless steel rotor and the CBB dye area during elution step. Protocol as described in the Figure 2 caption. 


\section{References}

1. Conway WD. Countercurrent chromatography: apparatus, theory, and applications: VCH Publishers, Weinheim, Germany, 1990.

2. Ito Y, Conway WD. High-speed countercurrent chromatography. Critical review in Analytical Chemistry,volume 17, 1986.

3. Berthod A. Countercurrent Chromatography: the support-free liquid stationary phase, Comprehensive Analytical Chemistry (Barceló D. Ed.), Volume XXXVIII, 2002.

4. $\quad \mathrm{Xu}$ Z, Lin X, Lu Y. Separation of Peptides and Proteins by Countercurrent Chromatography. Current Proteomics. 2013; 10(4): 322-333.

5. Mekaoui N, Faure K, Berthod A. Advances in countercurrent chromatography for protein separations. Bioanalysis. 2012; 4(7): 833-844.

6. Hatti-Kaul R. Aqueous two-phase systems. A general overview. Mol Biotechnol. 2001; 19(3): 269-277.

7. Raja S, Murty VR, Thivaharan V, Rajasekar V, Ramesh V. Aqueous two phase systems for the recovery of biomolecules-a review. Science and Technology. 2011; 1(1): 7-16.

8. Rosa P, Azevedo A, Sommerfeld S, Bäcker W, Aires-Barros M. Aqueous two-phase extraction as a platform in the biomanufacturing industry: economical and environmental sustainability. Biotechnol adv. 2011; 29(6): 559-567.

9. Grudzień $Ł$, Madeira L, Fisher D, Ma J, Garrard I. Phase system selection with fractional factorial design for purification of recombinant cyanovirin- $\mathrm{N}$ from a hydroponic culture medium using centrifugal partition chromatography. J. Chromatogr. A. 2013; 1285: 57-68.

10. Oelmeier SA, Effio CL, Hubbuch J. High throughput screening based selection of phases for aqueous two-phase system-centrifugal partitioning chromatography of monoclonal antibodies. J Chromatogr A. 2012; 1252: 104-114.

11. Wallhäußer E, Hussein M, Becker T. Detection methods of fouling in heat exchangers in the food industry. Food Control. 2012; 27(1): 1-10.

12. Dat NM, Hamanaka D, Tanaka F, Uchino T. Surface conditioning of stainless steel coupons with skim milk solutions at different $\mathrm{pH}$ values and its effect on bacterial adherence. Food Control. 2010; 21(12, Supplement): 1769-1773.

13. Sakiyama T, Sato K, Tsuda S, Sugiyama H, Hagiwara T. Citric acid pretreatment for suppressing adhesion of major egg allergens to a stainless steel surface. Food Control. 2013; 32(2): 702-706.

14. FDA. Guide to Inspections of Validation of cleaning Processes. (7/93), 1993.

15. Chollet $\mathrm{S}$. Rationalisation des critères de dimensionnement d'une colonne de chromatographie de partage centrifuge, thesis, University of Nantes, 211p, 2013.

16. Bradford MM. A rapid and sensitive method for the quantitation of microgram quantities of protein utilizing the principle of protein-dye binding. Anal Biochem. 1976; 72(1-2): 248-254.

17. Coussot G, Perrin C, Moreau T, Dobrijevic M, Le Postollec A, Vandenabeele-Trambouze O. A rapid and reversible colorimetric assay for the characterization of aminated solid surfaces. Anal Bioanal Chem. 2011; 399(3): 1061-1069.

18. Urano $\mathrm{H}$, Fukuzaki S. Kinetic study of desorption of two species of bovine serum albumin from alumina during alkali elution process. J Colloid Interface Sci. 2002; 252(2): 284-289.

19. Brizzolara RA. Adsorption of alginic acid to titanium investigated using $\mathrm{x}$-ray photoelectron spectroscopy and atomic force microscopy. Surf Interf Anal. 2002; 33(4): 351-360.

20. Takahashi K, Fukuzaki S. Cleanability of titanium and stainless steel particles in relation to surface charge aspects. Biocontrol Sci. 2008; 13(1): 9-16.

21. Georgiou CD, Grintzalis K, Zervoudakis G, Papapostolou I. Mechanism of Coomassie brilliant blue G250 binding to proteins: a hydrophobic assay for nanogram quantities of proteins. Anal Bioanal Chem. 2008; 391(1): 391-403.

22. Chial H, Splittgerber A. A comparison of the binding of Coomassie brilliant blue to proteins at low and neutral pH. Anal Biochem. 1993; 213(2): 362-369.

23. Chial $\mathrm{H}$, Thompson $\mathrm{H}$, Splittgerber A. A spectral study of the charge forms of Coomassie Blue G. Anal Biochem. 1993; 209(2): 258-266.

24. Schwienheer C, Merz J, Schembecker G. Investigation, comparison and design of chambers used in centrifugal partition chromatography on the basis of flow pattern and separation experiments. J Chromatogr A. 2015; 1390: 39-49. 
402

403

404
25. Marchal L, Legrand J, Foucault A. Mass transport and flow regimes in centrifugal partition chromatography. AIChE j. 2002; 48(8): 1692-1704. 